\title{
REVIEW
}

doi:10.3846/limes.2010.19

\section{A BOOK ABOUT AN UNPROCLAIMED EMPIRE $^{1}$}

Prof. Zenonas Norkus known as an excellent lecturer and author of the books devoted to philosophy of history (Historika. Istorijos ivadas, 1996), to Max Weber in the context of rational choice (Max Weber und Rational Choice, 2001), to regional political order from sociological viewpoint (Kokia demokratija, koks kapitalizmas? Pokomunistinè transformacija Lietuvoje lyginamosios istorinès sociologijos požiūriu, 2008) surprised the scientific society with a new book An Unproclaimed Empire. The Grand Duchy of Lithuania from the Viewpoint of Comparative Historical Sociology (2009) for some reasons.

Firstly, this book confirms the reputation of the author having exceptionally broad interests that cover phenomenology (doctoral thesis), theory and history of sociology (sociological approach in different books, as well the book Norkus 2001), philosophy of history (Norkus 1996), certain problems of analytical philosophy (lectures, as well the book Norkus 2001), political philosophy and social economics (Norkus 2008). Despite these unusually broad interests for a person, who represents a time of specialized work instead of Renaissance epoch, every his book is an exercise of sharp investigation by an interdisciplinary scalpel. This big book (474 pages) devoted to one question (whether GDL had been an empire?) is not the exception, too. By answering to this historical-philosophical question the author uses the criterions of empire's sociology. In this way a narrow question raised by Norkus ploughed up the broad scientific field including philosophy, history, and sociology.

Secondly, the philosophers usually deal with such global problems of human kind as principles of being, cognition of the world or universal morality. That is why the author calls himself modestly a sociologist instead of a philosopher whereas in the company of the historicists he calls himself a worker of the train instead of a soldier of the front in an ironic way. Although he refers in this way to the used historical literature instead of historical sources, Norkus introduces a new historical conception by following the thesis that GDL had been an empire. By grounding his thesis Norkus uses all kinds of scientific weaponry including comparison, sociological data, analytical argumentations, as well historical approach (concerning both the development of a concept and of a society). I suppose, after such kind of an offensive in the historical front instead of being in the rearguard, no local historicist could ignore this book in the field of his research.

\footnotetext{
${ }^{1}$ Norkus, Z. 2009. Nepasiskelbusioji imperija. Lietuvos Didžioji Kunigaikštija lyginamosios istorinès imperiju sociologijos požiūriu. Vilnius: Aidai.
} 
This locality presupposes the third aspect I would like to consider. Locality here refers to a region that transgresses the border of one country because of its historical role in the becoming of Central Europe. That is why this book has no way only the local meaning. This book could be a case of cultural regionalistics that covers the social aspects of historical phenomena of our future existential region. In other words, the author ploughs up not only a scientific region, not only a historical region that takes part in our public creation, but also a region of our responsible coexistence. In this way Norkus' scalpel exposes the way from certain local historical being to the very philosophical field.

The last but not least thing that surprises is the attractiveness that follows namely from the interest of the readers in the fate and future of their region. In other words, Norkus demonstrates an imagined community of GDL's fans, to whom the writer of these lines belongs too.

Tomas Kačerauskas 